\title{
First evidence of active transpressive surface faulting at the front of the eastern Southern Alps, northeastern Italy: insight on the 1511 earthquake seismotectonics
}

\author{
Emanuela Falcucci ${ }^{1}$, Maria Eliana Poli $^{2}$, Fabrizio Galadini ${ }^{1}$, Giancarlo Scardia ${ }^{3}$, Giovanni Paiero ${ }^{2}$, and \\ Adriano Zanferrari ${ }^{2}$ \\ ${ }^{1}$ Istituto Nazionale di Geofisica e Vulcanologia, Via di Vigna Murata 605, Rome, Italy \\ ${ }^{2}$ Dept. of Agricultural, Food, Environmental and Animal Sciences, University of Udine, Udine, Italy \\ ${ }^{3}$ Instituto de Geociências e Ciências Exatas, Universidade Estadual Paulista (UNESP), Rio Claro, São Paulo, Brazil \\ Correspondence: Emanuela Falcucci (emanuela.falcucci@ingv.it)
}

Received: 1 December 2017 - Discussion started: 2 January 2018

Revised: 7 May 2018 - Accepted: 18 May 2018 - Published: 18 July 2018

\begin{abstract}
We investigated the eastern corner of northeastern Italy, where a system of NW-SE-trending dextral strike-slip faults of western Slovenia intersects the south-verging fold and thrust belt of the eastern Southern Alps. The area suffered the largest earthquakes of the region, among which are the $1511\left(M_{\mathrm{w}} 6.3\right)$ event and the two major shocks of the 1976 seismic sequence, with $M_{\mathrm{W}}=6.4$ and 6.1. The Colle Villano thrust and the Borgo Faris-Cividale strike-slip fault have been here first analyzed by interpreting industrial seismic lines and then by performing morphotectonic and paleoseismological analyses. These different datasets indicate that the two structures define an active, coherent transpressive fault system that was activated twice in the past two millennia, with the last event occurring around the 15th-17th century. The chronological information and the location of the investigated fault system suggest its activation during the 1511 earthquake.
\end{abstract}

\section{Introduction}

The Late Miocene-Quaternary counterclockwise rotation and contemporaneous northward drift of the Adria microplate indenter resulted in the development of the eastern Southern Alps, which are connected to the Dinarides towards the east. The Adria microplate kinematics determined diffuse dextral strike-slip deformation in Slovenia and prevailing thrusting at the eastern Southern Alps, in northeastern
Italy (Zanferrari et al., 2013; Poli and Renner, 2004). Seismicity reflects such a kinematic transition, being characterized by both earthquakes caused by dextral strike-slip and reverse ruptures (Kastelic et al., 2008). This issue is by all means relevant considering that this region has been the focus of some of the strongest historical earthquakes of continental Europe, among which are the $1348\left(M_{\mathrm{w}} 6.6\right)$ and the $1511\left(M_{\mathrm{w}} 6.3\right)$ events, as well as the two major shocks of the 1976 seismic sequence $\left(M_{\mathrm{W}} 6.4\right.$ and 6.1). In particular, despite the large number of studies (e.g., Ambraseys, 1976; Ribaric, 1979; Bavec et al., 2013), the epicenter, the causative fault(s) and the kinematics of the 1511 earthquake are still a matter of debate. Here, we describe the results of a multi-disciplinary study performed in the 1511 earthquake area, based on geological-geomorphological surveys, industrial seismic line interpretation, paleoseismological trenching and the drilling of a $20 \mathrm{~m}$ deep core. Specifically, we focus on the Borgo Faris-Cividale fault (henceforth BFCF), a dextral strike-slip structure that experienced a complex kinematic history (e.g., Zanferrari et al., 2008a, 2013), and the Colle Villano thrust (henceforth CVT), which shows geomorphic hints of recent activity (Galadini et al., 2005). We aim to understand the relationship between these very close structures and their role in the regional structural-kinematics framework, and to acquire new clues on the 1511 earthquake seismotectonics. 

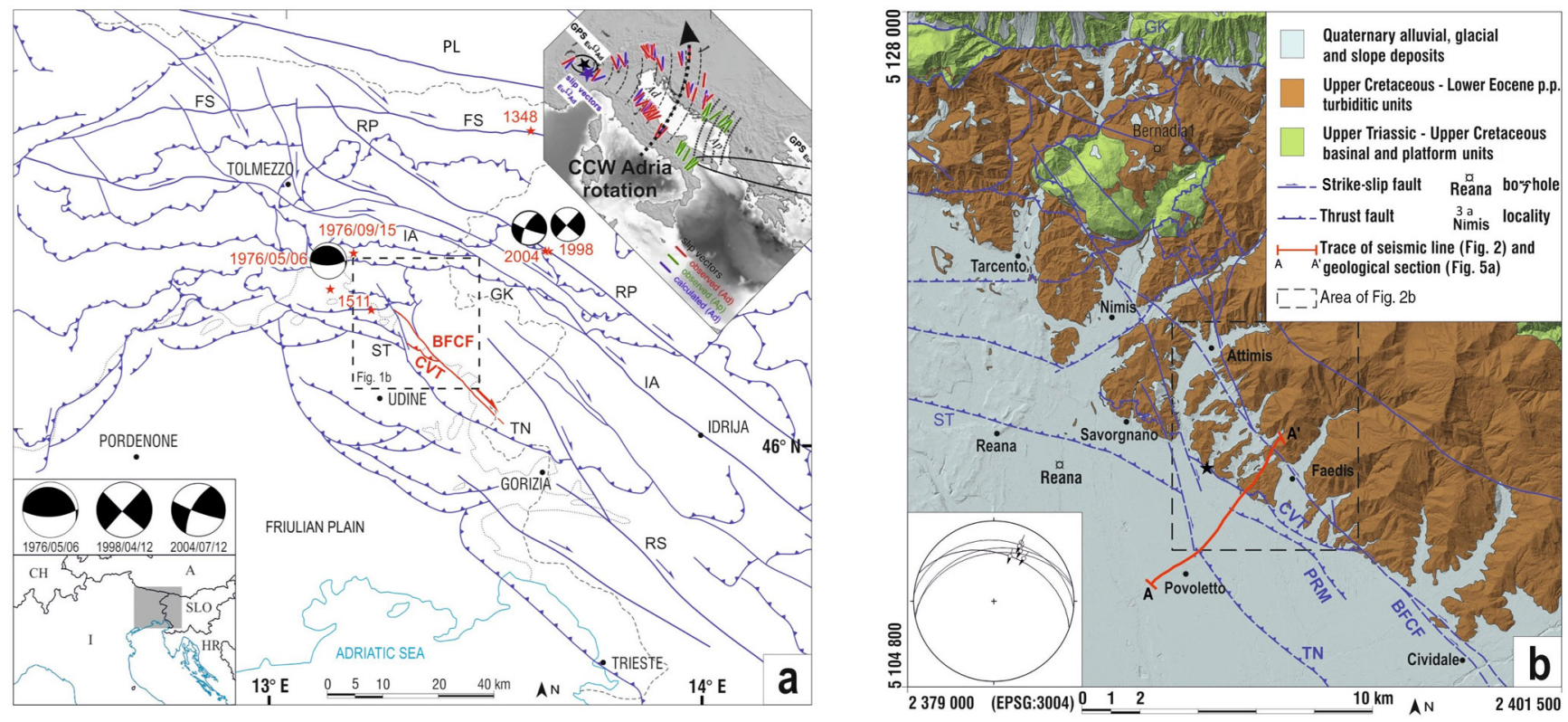

Figure 1. (a) Tectonic map of the eastern Southern Alps and western Dinarides (modified from Zanferrari et al., 2013). Adria counterclockwise rotation (D'Agostino et al., 2008), inset; BFCF: Borgo Faris-Cividale fault; CVT: Colle Villano thrust; GK: Gemona-Kobarid thrust; IA: Idrija-Ampezzo fault; PL: Periadriatic lineament; RP: Ravne-Paularo fault; RS: Raša fault; ST: Susans-Tricesimo thrust; TN: Trnovo nappe thrust front (Placer et al., 2010). Red stars: epicenters of the strongest historical and instrumental earthquakes (Rovida et al., 2016) and the related focal plane solutions. Italian boundary, thin dashed line. Hills-plain boundary, dotted lines. (b) Geological map of the study area (modified from Carulli, 2006; Zanferrari et al., 2008a, 2013). PRM: Premariacco thrust. Paleoseimological trench site, black star. Stereographic projection (lower hemisphere) of calcite slickenlines collected on the CVT, inset.

\section{Tectonic setting and seismic activity}

Since the Middle Miocene, the SSE-verging and WSWENE-trending fronts of the eastern Southern Alps in the Friuli region (Fig. 1a) (e.g., Castellarin et al., 2006, and references therein) cut and refolded the external Paleogene Dinarides compressive structures (e.g., Doglioni and Bosellini, 1987; Zanferrari et al., 2013). At the Miocene-Pliocene transition, the counterclockwise rotation of the Adria microplate produced dextral strike-slip deformation in Slovenia (e.g., Marton et al., 2003; Vrabec and Fodor, 2006). Recent activity of dextral strike-slip fault systems is documented by large right-lateral offset of geological and geomorphological features (e.g., Mlakar, 1969; Cunningham et al., 2006, 2007; Moulin et al., 2014, 2016) and by the formation of pullapart basins (Vrabec, 1994; Kastelic et al., 2008). Seismicity also reflects dextral strike-slip deformation, with major earthquakes having transcurrent focal plane solutions (e.g., Poljak et al., 2010), such as the 12 April 1998 ( $M_{\mathrm{w}}$ 5.66) (Bajc et al., 2001; Zupancîč et al., 2001; Bernardis et al., $2000)$ and 12 July $2004\left(M_{\mathrm{w}} 5.1\right)$ earthquakes, related to the Ravne strike-slip fault (Kastelic et al., 2008). Quaternary activity of the eastern Southern Alps front is documented by field evidence and seismic lines interpretation (e.g., Zanferrari et al., 1982, 2008a, b, 2013; Galadini et al., 2005; Poli et al., 2008, 2009; Monegato and Poli, 2015), which defined ongoing growth of anticlines on blind active thrusts. The two aforementioned main shocks of the 1976 seismic sequence, in central Friuli, show reverse fault plane solutions, along low-angle WNW-ESE- to E-W-striking and N-dipping reverse faults (Fig. 1a) (Slejko et al., 1999; Pondrelli et al., 2001; Poli et al., 2002), recently confirmed by geodetic data analysis and inversion (Cheloni et al., 2012). Interseismic geodetic data show about $2 \mathrm{~mm} \mathrm{yr}^{-1}$ northwards movement of Adria relative to Eurasia (e.g., D' Agostino et al., 2008; Devoti et al., 2011; Carafa and Bird, 2016) (Fig. 1a). This is absorbed by WSW-ENE-trending, SSE-verging thrust front of the eastern Southern Alps and by NW-SE-trending, rightlateral strike-slip fault systems in western Slovenia. The major historical earthquake of the study area struck in March 1511 (maximum intensity $=\mathrm{IX}^{\circ}$ MCS scale). In spite of many studies, many issues still remain to be solved about this event. Ambraseys (1976) suggested $M \sim 6.4$ and epicenter located northwest of Tolmin, at the Italy-Slovenia border. Ribaric (1979) suggested that the event had been actually made of two shocks, one occurring at 15:00 CET in the Idrija zone, in Slovenia, with a possible magnitude of 6.9, and a second at 20:00 CET east of Gemona, in Friuli, with a possible magnitude of 7.0-7.2. Košir and Cecić (2011) questioned Ribaric's interpretation of the historical information and proposed a single main shock on 26 March at 14:40 GMT. By inverting macroseismic data, Fitzko et al. (2005) hypothe- 
sized a possible source of the 1511 earthquake on a $50 \mathrm{~km}$ long segment of the Idrija fault, in Slovenia. The authors proposed northwestward rupture directivity, with nucleation just to the SE of Idrija. This hypothesis is also assumed by the Italian Database of Individual Seismogenic Sources (Basili et al., 2008). Nonetheless, as reported by Fitzko et al. (2005), their model only partly reconciles the actual intensities suffered by many villages in Italy and Slovenia. Indeed, some synthetic intensity data points differ by up to $2^{\circ}$ from the intensities estimated by the historical sources. Moreover, a recent reappraisal of macroseismic data led to a new distribution of intensities (Camassi et al., 2011), where values are strongly decreased in Slovenia. In particular, the intensity of $X$ assigned to Idrija, which was a key point in the Fitzko et al. (2005) hypothesis, has been removed. Also, Camassi et al. (2011) proposed a new epicenter for the 1511 event in Italy, near Tarcento, and Rovida et al. (2016) defined $M_{\mathrm{w}}$ as 6.3 .

\section{Structural observations and seismic line interpretation}

The BFCF is a $\sim 25 \mathrm{~km}$ long, NW-SE-striking dextral strikeslip fault, traceable from Nimis to the north, to Cividale to the south (Fig. 1a, b) (Moulin et al., 2016). Southwest of the BFCF occurs the CVT, a $10 \mathrm{~km}$ long, WNW-ESEstriking thrust. Kinematic indicators (calcite slickenlines) show a southwestward vergence (Fig. 1b, inset). The fault front crops out at the base of small reliefs made of early Eocene turbidites (Savorgnano marls and arenites in Zanferrari et al., 2008a) (Fig. 1b), which have been folded and uplifted by the thrust activity. The BFCF and CVT merge towards the SE (Fig. 1b). Interpretation of an industrial seismic line (kindly provided by ENI E\&P) allowed us to define the deep geometry of the two structures (Fig. 2). The CVT cuts the Quaternary succession and seems to be connected at depth with the BFCF, representing a branching from the same major structure. Two further thrusts (Premariacco thrust and Tarnovo thrust, i.e., PRM and TN in Fig. 1b, respectively) are also interpretable in the CVT footwall, deforming the base of the Quaternary. The seismic reflection line also shows the CVT reaching the surface. Moving from this evidence, we focused paleoseismological investigation along the CVT surface trace with the aim of constraining the recent movements of the fault.

\section{Morphotectonic evidence}

The sector between the CVT and BFCF is characterized by a low-gradient morphology, with flat sectors interposed to small NE-SW-elongated gentle reliefs. The streams run from the NE to the SW and get sinuous entering this low-gradient sector.
On the basis of morphological observations, Moulin et al. $(2014,2016)$ consider BFCF as an active fault, i.e., the northern portion of the Raša fault. In particular, in the study area, morphostructural evidence, such as suspended Quaternary glacis, diversions and deflections along the Valle, Poiana and Meris rivers and a series of aligned gaps (Zanferrari et al., 2008a; Marco Pascolino, unpublished data, 2014), suggests dextral horizontal movements of strike-slip fault (Fig. 3a).

Moving toward the SW (i.e., on the CVT hanging wall), because of the common water regulations, most of the rivers become rectilinear, getting sinuous again flowing toward the Friulian plain. Such a geomorphic setting suggests the formation of a low-gradient sector at the CVT rear, due to the progressive growth of the reverse tectonic structure. The presence of two back-tilted surfaces located at the boundary between the Friulian plain and the reliefs (Fig. 3a) corroborates this interpretation.

Moreover, we found remnants of an old paleolandscape on top of the ridges located between the CVT and BFCF, represented by almost flat land surfaces carved onto the turbidite bedrock. Interpolation of these top relict land surfaces (Fig. 3b) indicates northeastward dipping, which is opposite to the present drainage pattern.

In order to find further evidence of the recent activity of the CVT, we made a core boring $20 \mathrm{~m}$ deep just northward of the trenches' site (location in Fig. 3a), above an about $5 \mathrm{~m}$ raised fluvial terrace. The borehole (localized at $155 \mathrm{~m}$ a.s.1.) found about $3 \mathrm{~m}$ thick colluvial sandy silt. Underneath, $12 \mathrm{~m}$ thick grey-blue lacustrine deposits were cored. The drilling reached the bedrock (i.e., Savorgnano marls and arenites) at $15.40 \mathrm{~m}$ depth (Fig. 4).

Comparing the depth of bedrock in the trenches (Unit 8) with that in the borehole it appears that the Savorgnano marls and arenites constitute a morphostructural high whose progressive growth formed a local depocentre at its back (i.e., a piggyback basin), where a small lacustrine basin constituted by the grey-blue clays (Fig. 4). Within these deposits, a wood that has provided an age $>45000 \mathrm{BP}$ (radiocarbon cal. age, $2 \sigma$ ) has been found.

\section{Paleoseismological investigations along the CVT}

We dug three trenches across a gentle surface scarp $(\sim 0.5 \mathrm{~m}$ high) seen at the CVT front (Figs. 3a, 5a). The excavations exposed a continental sedimentary sequence, mainly consisting of fluvial and slope deposits that we subdivided into eight stratigraphic units (Figs. 5, 6) described here:

- Unit 1 consists of ploughed soil, made of brownish silt with sparse centimeter-size polygenic pebbles.

- Unit 2 consists of colluvial deposit made of yellowish/brownish sandy silt with sparse centimeter-size pebble and charcoal fragments. 


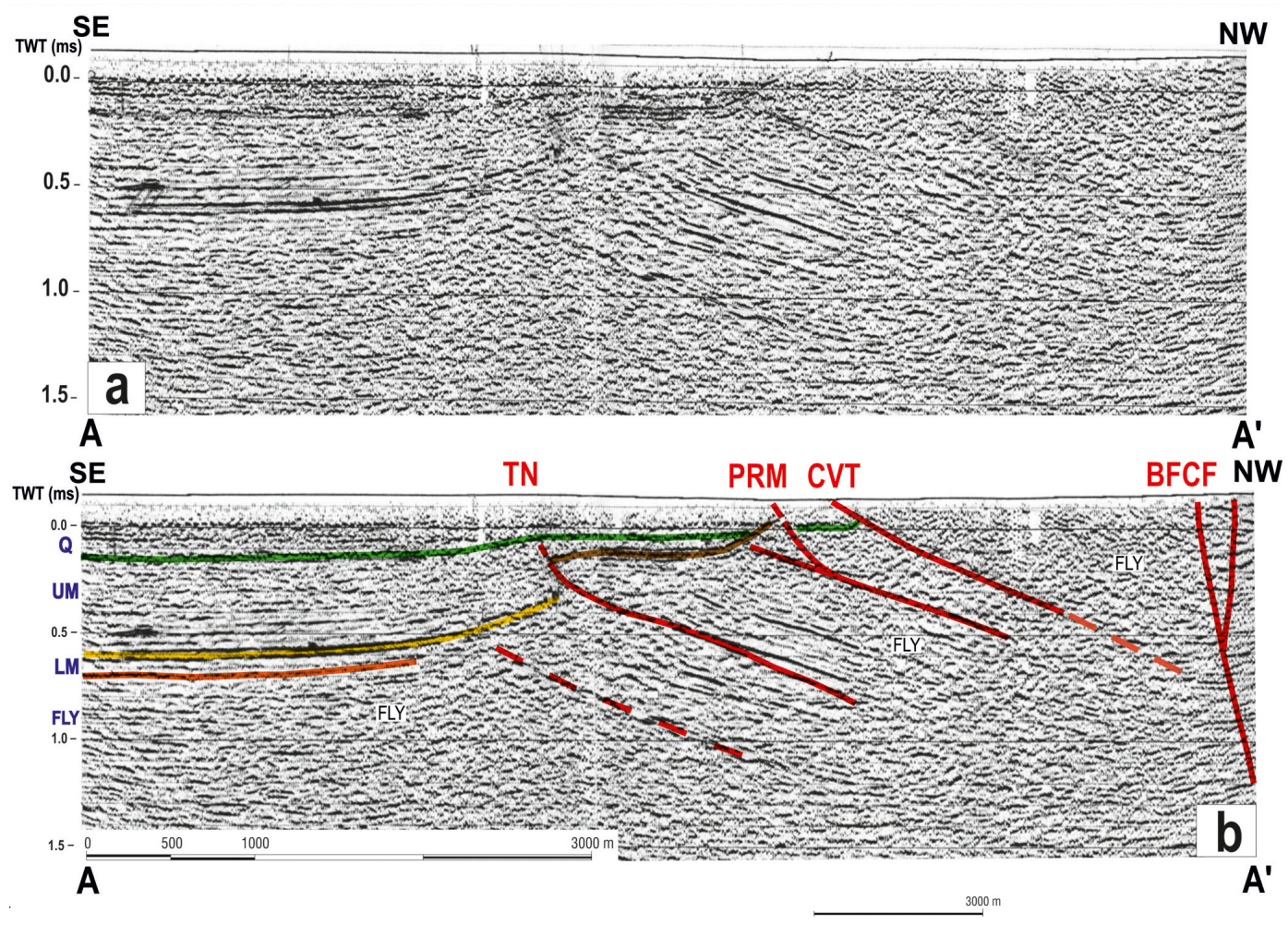

Figure 2. (a) Reflection seismic section crossing the study area; (b) interpretation (line drawing) of the reflection seismic section (A-A' in Fig. 1b). Q: Quaternary; UM: Middle-Upper Miocene Molasse; LM: Cavanella Group (Lower-Middle Miocene); FLY: Upper CretaceousLower Eocene p.p. turbiditic units.

- Unit 3 consists of colluvial deposit made of brownish massive sandy silt containing centimeter-size polygenic pebbles (mostly organized in gravel lenses), charcoal fragments and $\mathrm{Fe}-\mathrm{Mn}$ concretions.

- Unit 4 consists of alluvial deposit made of clastsupported gravel with brownish silty matrix.

- Unit 5: colluvial deposit made of massive yellowishbrownish sandy silt containing centimeter-size polygenic pebbles (mostly organized in gravel lenses), charcoal fragments and Fe-Mn concretions.

- Unit 6 consists of colluvial deposit made of yellowish and locally brownish clayey silt with sparse clasts $(10 \mathrm{~cm}$ maximum size). The deposit underwent pedogenesis which altered the surface of the clasts and the whole sediment structure, and determined the formation of Fe-Mn concretions.

- Unit 7 consists of alluvial deposit made of polygenic gravel (centimeter-size pebbles) laterally grading to clayey silt with sparse pebbles. The pebbles' lithology attests that the deposit has been fed by the Tagliamento River catchment.

- Unit 8 consists of bedrock represented by the Savorgnano marls and arenites (Ypresian, Early Eocene).
Chronologic constraints were provided by radiocarbon dating on charcoals found within the units (dating made by INNOVA SCARL laboratory) (Table 1). In this term, it must be underlined that the obtained ages all refer to charcoals, that have been included and transported by the alluvial and colluvial deposits from which we collected them. Therefore, the ages can be similar to each other or sparse. In light of this, we have only considered the most recent ages achieved for each unit as a terminus post quem for the unit deposition and thus for the deformation events.

The trenches show the whole stratigraphic succession warped (upward convexity) in coincidence with the surface scarp (Fig. 5b, c). The lowermost units (7 to 4) show a slightly tighter bending than the upper ones (Units 3 to 1). The very localized bending, the coincidence with the surface scarp and the sedimentological interpretation rule out that this geometrical feature relates to the original depositional attitude of the layers. This is particularly evident for the fluvial Unit 7, whose attitude is expected to be subhorizontal. Besides this evidence, each excavation showed other features (fractures and shear planes), described below, that can be associated with events of tectonic deformation (Figs. 5b, d, e, f and $6 a-c)$.

- Trench 1 (Figs. 5b and c, 6a): Unit 8 (turbidite bedrock) showed pervasive cleavage with subvertical planes 

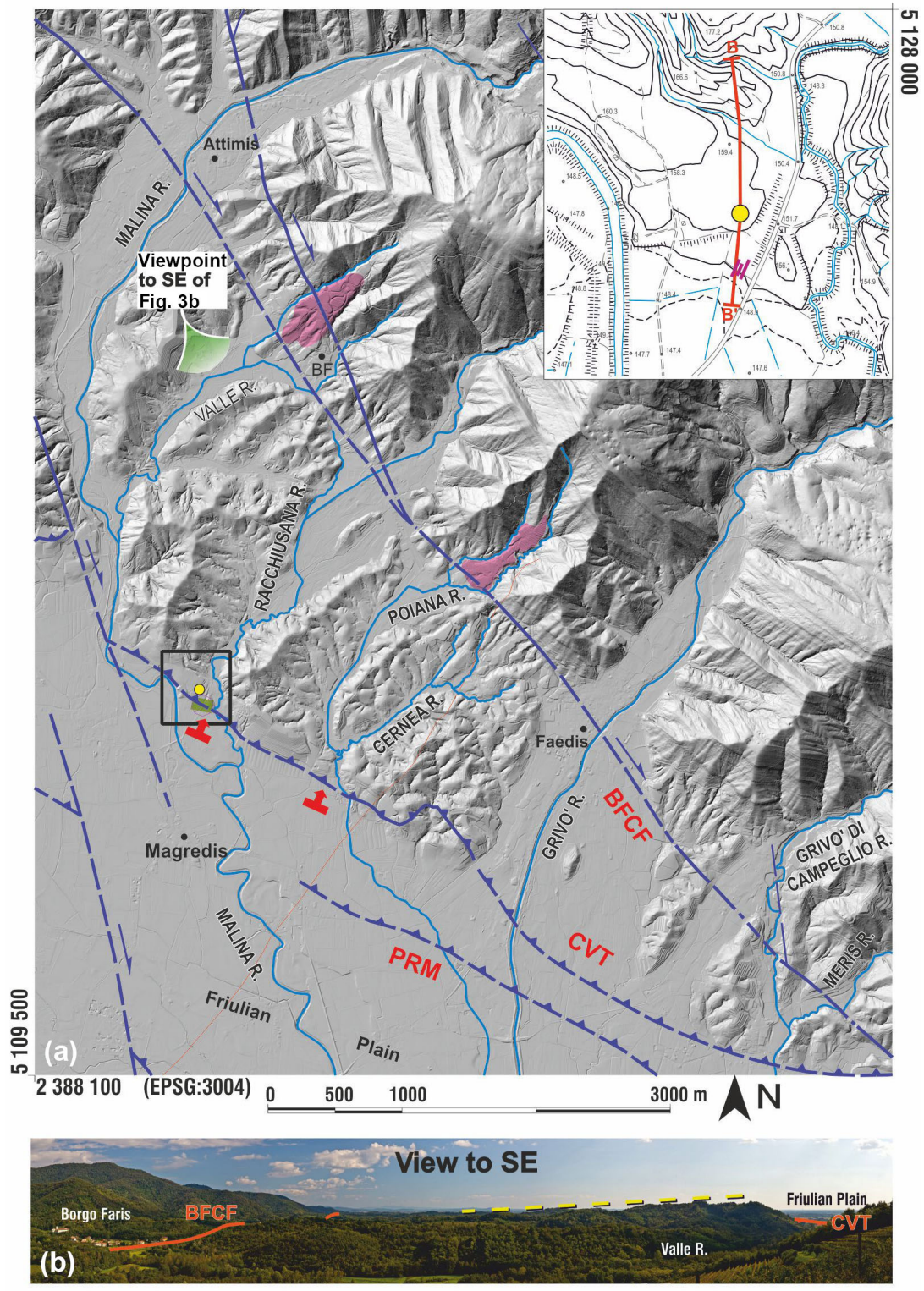

2401500

Figure 3. (a) Digital elevation model (supplied by Regione Friuli Venezia Giulia) of the study area. Faults: BFCF; CVT; PRM, Premariacco thrust; BF: Borgo Faris village. Back-tilted surfaces at the Racchiusana and Poiana valley outlets, red arrows. In pink are the two suspended Quaternary glacis cut off by the BFCF. The black square is detailed in the inset: site of the core logging, yellow dot; traces of the paleoseismological trenches, violet lines; BB', geological section of Fig. 4. Red line: seismic line of Fig. 2. (b) The NE-dipping paleolandscape carved in the turbidite bedrock (yellow dotted line) between the BFCF and the CVT. Point of view in Fig. 3a (green eye).

about E-W striking, indicative of localized shearing. Slope deposits of Unit 6 are unconformably overlaid by Unit 5. This suggests progressive deformation of the sequence during deposition, with the formation of angular unconformities, i.e., growth strata. Where the sedimentary sequence displayed warping in coincidence with the surface scarp $(\sim 0.5 \mathrm{~m}$ high$)$, Units 5 and 4 were also displaced by a low-angle shear plane. The displacement indicates reverse kinematics, with sense of motion towards the SW (Figs. 5b, 6a). The deformation was also accommodated by a secondary reverse shear plane with the opposite sense of displacement. These features were localized where the turbidite bedrock was affected by cleavage, thus demonstrating the presence of a welldeveloped shear zone active previously.

- Trench 2: we identified high-angle shear planes that offset Units 4 and 5 with an extensional kinematics and that were sealed by Unit 3 (Figs. 5d, 6b). The geometrical characteristics of the displaced units and the coinci- 


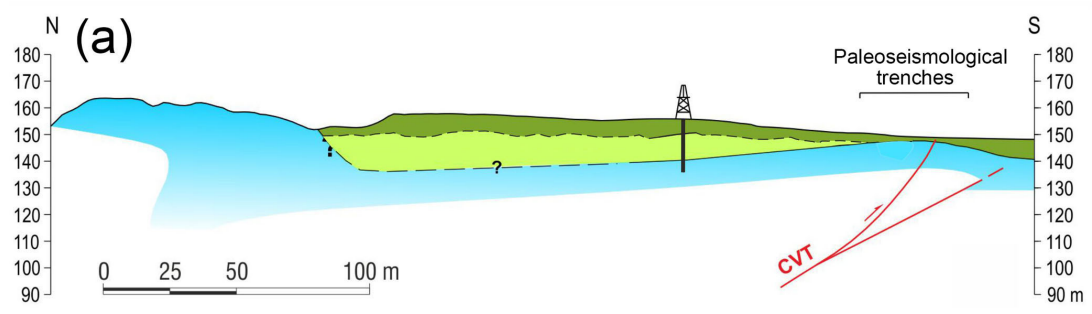

(b)

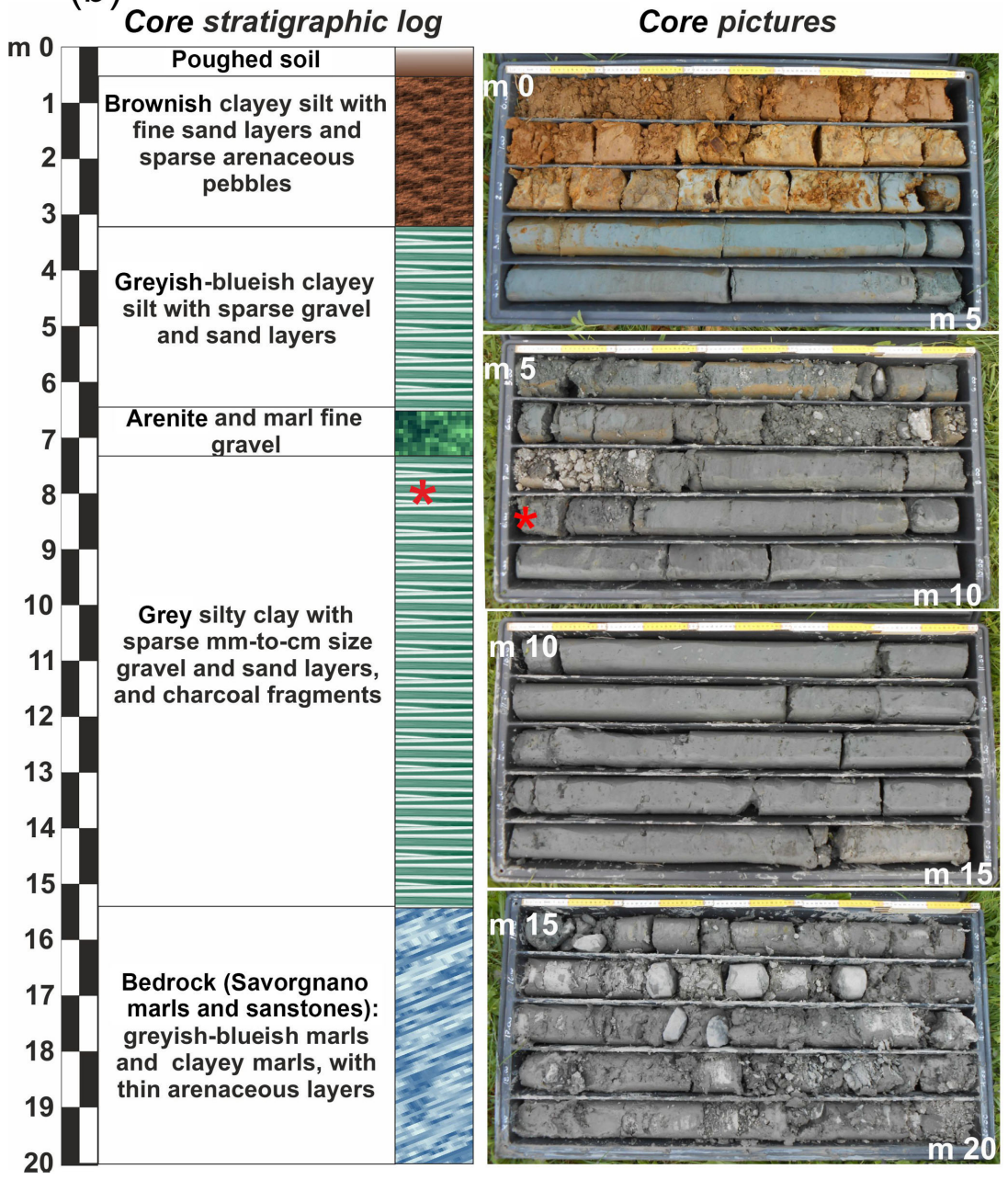

Figure 4. Geological cross section across the core logging and the paleoseismological trenches. The light green lacustrine clay does not crop out in the trenches but onlaps the growing anticline built in the turbiditic bedrock (light blue). Dark green: alluvial and colluvial deposits; light green: lacustrine deposits; blue: turbidite bedrock. In the lower panel, the stratigraphic log and pictures of the borehole. The red asterisk indicates the location of the sample which gave a radiocarbon age $>45000$ years. Borehole location: $46^{\circ} 09^{\prime} 07^{\prime \prime} \mathrm{N}, 13^{\circ} 18^{\prime} 28^{\prime \prime} \mathrm{E}$ (WGS84).

dence with the warped portion of the succession indicate that these shear planes define tension cracking related to bending, interpreted as an extrados-related feature (i.e., bending moment fracturing) due to a sudden warping event of the paleotopographic surface. This event occurred after deposition of Unit 4 and before Unit 3.

- Trench 3: comparably to trench 2, Units 4 to 6 are disrupted by an tensional fracture which, in turn, was sealed by Unit 3 (Fig. 6c). Moreover, in the easternmost part of the excavation, Unit 6 is brought into lateral contact with Unit 8 (turbidite bedrock) by a subvertical shear plane (Figs. 5e, f and 6c). This structural feature is sealed by Unit 5. Furthermore, in this sector, the basal contact of Unit 5 on the underlying Unit 8 gets slightly convex upward (Fig. 5e), suggesting that Unit 5 underwent slight uplift after deposition. 

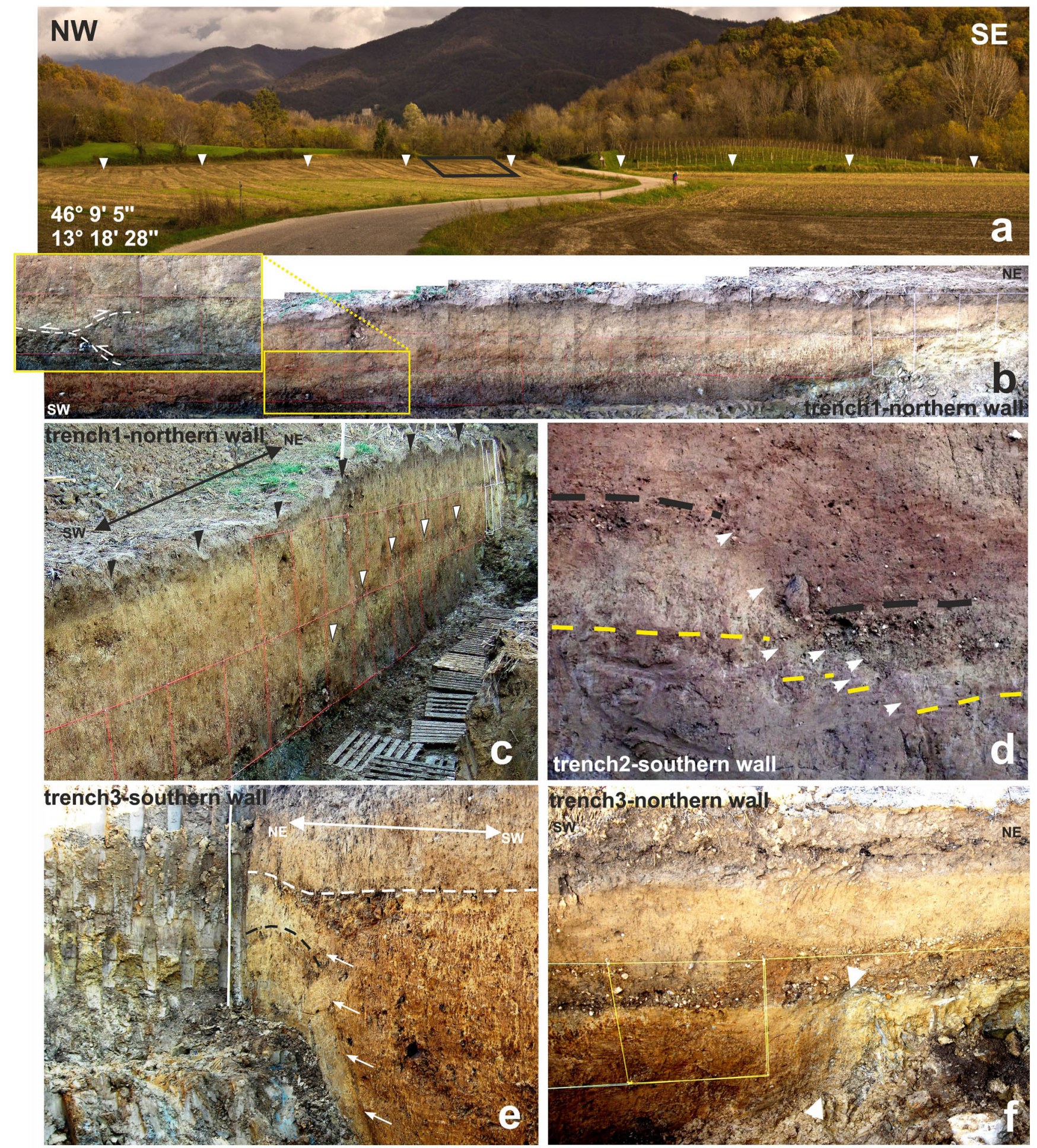

Figure 5. (a) Racchiusana valley outlet, north of Magredis. Trenches' location, black rectangle. (b) Trench 1, northern wall; reverse fault planes (white dashed lines in inset). (c) Trench 1, northern wall; bending (marked by white triangles) of the stratigraphic units in coincidence with the surface scarp (black triangles). (d) Trench 2, southern wall; fracture planes (indicated by white arrows) displacing the units (attitude marked by black and yellow dashed lines. (e) Trench 3, southern wall; shear plane (white arrows) displacing the upward warped stratigraphic units (black and white dashed lines). (f) Trench 3, northern wall, high-angle shear plane (white arrows) placing into contact the bedrock (Unit 8) with the late Quaternary units. 
Table 1. Detail of the radiocarbon dating performed on the collected charcoals (calibration curve by Reimer et al., 2013).

\begin{tabular}{llrll}
\hline $\begin{array}{l}\text { Sample } \\
\text { code }\end{array}$ & $\begin{array}{l}\text { Type of organic } \\
\text { material }\end{array}$ & $\begin{array}{r}\text { Radiocarbon age } \\
\text { (before the present) }\end{array}$ & $\begin{array}{l}\text { Calibrated } \\
\text { age }(2 \sigma)\end{array}$ & $\begin{array}{l}\text { Stratigraphic } \\
\text { unit }\end{array}$ \\
\hline Sample_1 & charcoal & $1469 \pm 33$ & $544-646$ AD & Unit 4 \\
Sample_2 & charcoal & $1503 \pm 42$ & $526-642$ AD & Unit 3 \\
Sample_3 & charcoal & $6060 \pm 79$ & $5211-4792$ BC & Unit 5 \\
Sample_4 & charcoal & $291 \pm 37$ & $1485-1792$ AD & Unit 2 \\
Sample_5 & charcoal & $5596 \pm 56$ & $4535-4344$ BC & Unit 5 \\
Sample_6 & charcoal & $1225 \pm 45$ & 674-893 AD & Unit 2 \\
Sample_7 & charcoal & $1026 \pm 75$ & $945-1047$ AD & Unit 2 \\
\hline
\end{tabular}
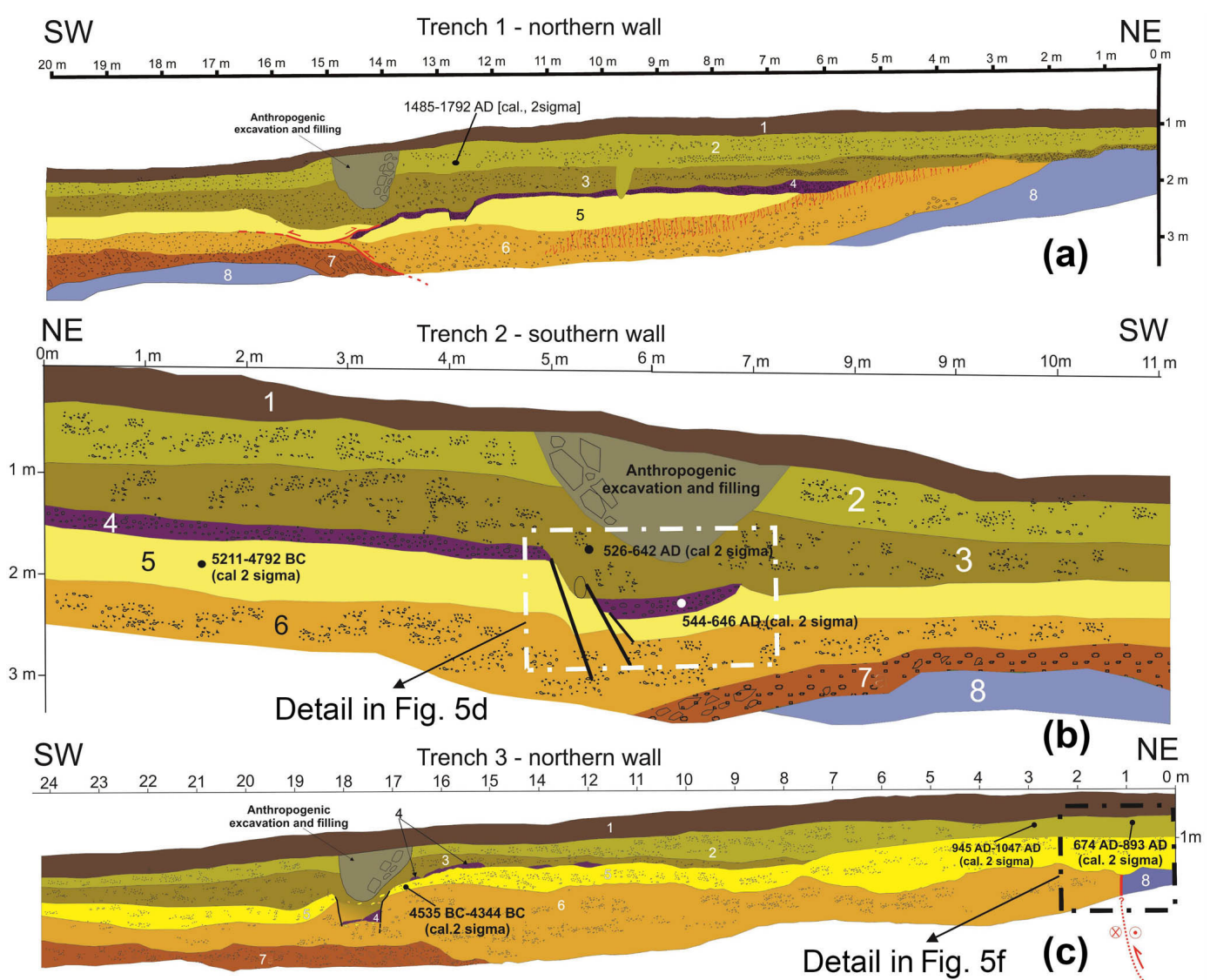

Figure 6. Trench walls, stratigraphic schemes. Units: 1, soil; 2, 3, 5 and 6, colluvial deposits; 4 and 7, fluvial deposits; 8, turbiditic bedrock.

The described evidence allows distinguishing at least three subsequent events of deformation: the oldest event, named E3, is documented by the displacement of Unit 6 along the subvertical shear plane which placed it into contact with the bedrock (seen in trench 3) and was sealed by Unit 5. E3 was thus responsible for the first surface faulting. The angular unconformity that separates Unit 5 from Unit 6 (described in trench 1) also supports the occurrence of E3, as Unit 6 has been deformed and tilted towards the SW before the deposition of Unit 5, determining an onlap geometry.

A subsequent event, named E2, is testified by primary and secondary tectonic features, i.e., the reverse fault planes (seen in trench 1), which offset the sequence up to Unit 4, and the extrados fractures (seen in trenches 2 and 3), that developed after Unit 4 deposition and before Unit 3 deposition, respectively. It is worth noting that notwithstanding extrados fractures are secondary surface effects, their formation requires sudden warping. Otherwise, slow and progressive deformation would have been "absorbed" by a continuous deformation of the sediments. The occurrence of E2 is also suggested by the upward bending of Unit 5 overlaying the bedrock (Fig. 5e).

The latest event, named E1, is documented by the gentle warping of Units 3 to 1 (seen in all of the trenches), which 


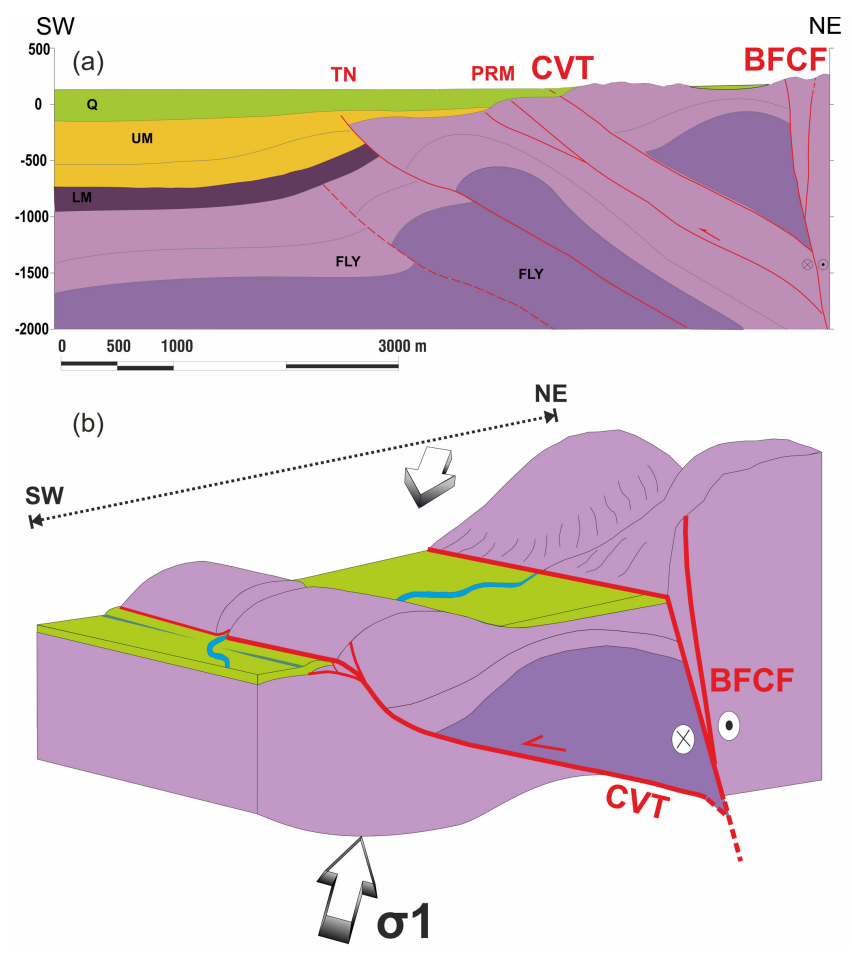

Figure 7. Geological cross section based on the seismic line of Fig. 2 ( $\mathrm{AA}^{\prime}$ in Fig. 1b) and 3-D scheme (b) of the BFCFCVT system. Q: Quaternary; UM: Middle-Upper Miocene Molasse; LM: Cavanella Group (Lower-Middle Miocene); FLY: Upper Cretaceous-Lower Eocene turbiditic sequence. TN: Tarnovo nappe front (according to Placer et al., 2010).

matches the bending radius of the surface scarp. As Units $3-$ 1 display a lower bending than the underlying Units $7-4$, it testifies that the older units underwent a larger, cumulative deformation produced by E2 and E1.

The radiocarbon ages allow us to constrain E3 before the 5th millennium BC, based on the ages obtained from charcoals collected within Unit 5, which sealed the event. As for E2, it may be constrained between the 5th and 6th century AD. In particular, charcoals found within Units 4 and $3-$ the former displaced by E2 and the latter sealing E2 - provided a radiocarbon age $\sim 6$ th century AD. Even if the radiocarbon age obtained from the charcoal collected in Unit 3 represents a terminus post quem for the unit deposition, the similarity between its age and the age obtained from the charcoal collected in Unit 4 (i.e., 6th century AD) allows to hypothesize that E2 likely occurred around this period. Lastly, E1 took place after the 15th century $\mathrm{AD}$, based on the youngest radiocarbon age of charcoals found within Unit 2.

\section{Discussion and concluding remarks}

We performed multiple investigations on the CVT and the strike-slip BFCF. These structures are located at the inter-

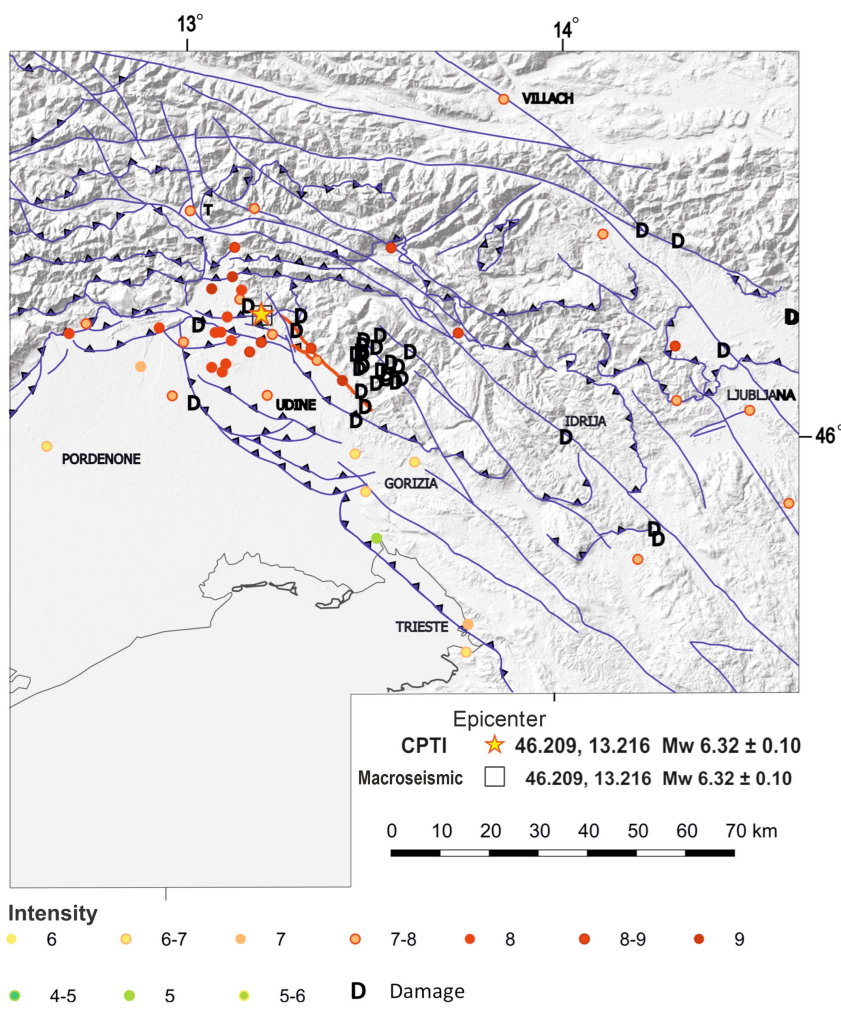

Figure 8. Damage distribution of the 1511 earthquake from CPTI (Rovida et al., 2016; Locati et al., 2016); red lines, BFCF-CVT system.

section between the Slovenian dextral strike-slip active shear zone and the external active thrust front of the eastern Southern Alps. Our main goal was to investigate how active tectonic deformation distributes in this region of kinematic transition, and to improve the seismotectonic knowledge of the area, still incomplete in some important aspects, such as the causative fault of the largest earthquake of the study region, which occurred in 1511.

Field observations coupled with the interpretation of a commercial seismic reflection line indicate that the BFCF and CVT gave rise to a major NW-SE- to WNW-ESEstriking transpressive shear zone that accommodates reverseoblique deformation. This interpretation fits the GPS time series available for the area, which define main $\mathrm{N}-\mathrm{S}$-trending shortening. Therefore, a significant horizontal shear component is inherently expected on structures obliquely oriented with respect to the $\mathrm{N}-\mathrm{S}$-trending regional $1 \sigma$, i.e., the axis of maximum compression. In terms of kinematic relation between the two faults, the following evidence suggest that they are the surface expression - as fault splays - of a complex fault system that accommodates transpressive tectonic deformation affecting this region: (i) the narrow spacing (in plan view) between the two structures (towards the south, the two structure merge, as we depicted in Fig. 1); (ii) the deep structural arrangement, achieved by the interpretation 
of the provided seismic lines, which suggests that the Colle Villano thrust is a rather superficial splay that connects to the Borgo Faris-Cividale fault and does not cut across it; and (iii) the transpressive deformations we observed along the trench walls (testified by both compressive faults and deformations, and subvertical strike-slip shear planes) point to the Borgo Faris-Cividale fault as major strike-slip fault, which accommodates the horizontal tectonic deformation, and the Colle Villano thrust as a synthetic splay that accommodates the contractional component. The evidence of active deformation we found along the CVT and the available knowledge on the kinematics of the region suggest that the transpressive slip probably splits on the investigated structures, that is, mainly strike-slip along the BFCF and mainly compressive along the CVT (Fig. 7). Slip partitioning on splays of oblique structures has been observed in many cases from across the world, both as for the coseismic and long-term displacements (e.g., Wesnousky and Jones, 1994; Walker et al., 2003; King et al., 2005). In the tectonic-structural perspective, our inferences match the geodetic observations made by Devoti et al. (2011) who, based on GPS time series, issued a certain amount of horizontal shear in this region. Moreover, Montone and Mariucci (2016) show that the contemporary stress map of Italy shows that this region is located at the transition between strike-slip faulting and thrust faulting, and transpressive deformation is expected.

Trench investigations across the CVT attested to at least three activation events. The presence of low-angle reverse faults, the displacement of some stratigraphic units along subvertical shear planes and the occurrence of secondary extrados fractures are indicative of sudden deformation events along the CVT, responsible for primary surface faulting. In detail, chronological data attested to the penultimate event E2 likely around the 6th century AD and the last event E1 after the 15th century AD. E1 has been responsible for bending that caused $\sim 0.5 \mathrm{~m}$ high (minimum) surface scarp. From a seismotectonic viewpoint, the only known post- 15 th century $\mathrm{AD}$ earthquake of the area that has had a magnitude large enough to result in such a significant deformation is that which occurred in 1511. In this perspective, based on the regressions of Wells and Coppersmith (1994), the magnitude of the earthquake, i.e., 6.3 (Camassi et al., 2011; Rovida et al., 2016) is consistent with the activation of the $25 \mathrm{~km}$ long CVT-BFCF system. Therefore, the CVT-BFCF system appears as a very plausible candidate for having played a primary role in the seismogenic process of the 1511 seismic event (Fig. 8). Ultimately, this study raises significant issues on a potential major seismogenic source of a region where interseismic coupling suggests elastic strain is building up at seismogenic depths which will be released in future large earthquakes (Cheloni et al., 2014; Serpelloni et al., 2016).

Data availability. All of the data that are not the result of field investigations are accessible at the CARG Project - Geologic and geothematic cartography (http://www.isprambiente.gov.it/en/ projects/soil-and-territory/carg-project-geologic-and-geothematiccartography), sheets 049, 065 and 066 (Zanferrari et al., 2008a, b, 2013).

Author contributions. EF, first and corresponding author, led the paleoseismological investigations, manuscript writing and discussed the seismotectonic interpretation; MEP and AZ performed the geological, morphological and structural analysis and interpretation of the reflection seismic line; GS contributed to the stratigraphic interpretation of the trench walls; GP contributed to the trenching activity; seismotectonic interpretation was discussed and shared with FG. All of the authors discussed the paleoseismological data and general aspects concerning the regional tectonic framework.

Competing interests. The authors declare that they have no conflict of interest.

Acknowledgements. The authors are grateful to the reviewers (Dario Zampieri and Luke Wedmore) for improving our manuscript and work with their constructive and helpful comments and suggestions. The study has been funded by the ASSESS project, Regione Friuli Venezia Giulia - Istituto Nazionale di Geofisica e Vulcanologia (INGV) agreement, Project Manager for INGV Fabrizio Galadini. The borehole was made by means of CARG Project funds managed by Adriano Zanferrari. The authors thank Stefano Gori for the helpful discussion on active tectonics, structural and paleoseismological issues, and Andrea Marchesini for helping us with the figures' preparation.

Edited by: Mark Allen

Reviewed by: Luke Wedmore and Dario Zampieri

\section{References}

Ambraseys, N. N.: The Gemona di Friuli earthquake of 6 May 1976, in: Unesco Restricred Technical Report RP/1975-76 2.222.3, edited by: Pichard, P., Ambraseys, N. N., and Ziogas, G. N., Paris, France, 1976.

Bajc, J., Aoudia, A., Sarao, A., and Suhadolc, P.: The 1998 BovecKrn mountain (Slovenia) earthquake sequence, Geophys. Res. Lett., 28, 1839-1842, 2001.

Basili, R., Valensise, G., Vannoli, P., Burrato, P., Fracassi, U., Mariano, S., and Tiberti, M. M.: The Database of Individual Seismogenic Sources (DISS), version 3: summarizing 20 years of research on Italy's earthquake geology, Tectonophysics, 453, 2043, 2008.

Bavec, M., Atanackov, J., Celarc, B., Hajdas, I., Jamšek Rupnik, P., Jež, J., Kastelic, V., Milanič, B., Novak, M., Skaberne, D., and Žibret, G.: Evidence of Idrija fault seismogenic activity during the Late Holocene including the $1511 \mathrm{Mm} 6.8$ earthquake, Proceedings of the 4th International INQUA Meeting on Paleoseismology, Active Tectonics and Archeoseismology (PATA), 9-14 October 2013, Aachen, Germany, 2013. 
Bernardis, G., Poli, M. E., Snidarcig, A., and Zanferrari, A.: Seismotectonic and macroseismic characteristics of the earthquake of Bovec (NW Slovenia: April 12, 1998), B. Geofis. Teor. Appl., 41, 133-148, 2000.

Camassi, R., Caracciolo, C. H., Castelli, V., and Slejko, D.: The 1511 Eastern Alps earthquakes: a critical update and comparison of existing macroseismic datasets, J. Seismol., 15, 191-213, 2011.

Carafa, M. M. C. and Bird, P.: Improving deformation models by discounting transient signals in geodetic data, 2: Geodetic data, stress directions, and long-term strain rates in Italy, J. Geophys. Res., 121, 5557-5575, https://doi.org/10.1002/2016JB013038, 2016.

Carulli, G. B.: Carta geologica del Friuli Venezia Giulia alla scala $1: 150.000$. Regione Autonoma Friuli Venezia Giulia, Direzione Centrale Ambiente e Lavori Pubblici, Servizio Geologico, SELCA, Firenze, Italy, 2006.

Castellarin, A., Nicolich, R., Fantoni, R., Cantelli, L., Sella, M., and Selli, L.: Structure of the lithosphere beneath the Eastern Alps (southern sector of the TRANSALP transect), Tectonophysics, 414, 259-282, 2006.

Cheloni, D., D'Agostino, N., D’Anastasio, E., and Selvaggi, G.: Reassessment of the source of the 1976 Friuli, NE Italy, earthquake sequence from the joint inversion of high-precision levelling and triangulation data, Geophys. J. Int., 190, 1279-1294, https://doi.org/10.1111/j.1365-246X.2012.05561.x, 2012.

Cheloni, D., D'Agostino, N., and Selvaggi, G.: Interseismic coupling, seismic potential and earthquake recurrence on the southern front of the Eastern Alps (NE Italy), J. Geophys. Res.-Sol. Ea., 119, 4448-4468, https://doi.org/10.1002/2014JB010954, 2014.

Cunningham, D., Grebby, S., Tansey, K., Gosar, A., and Kastelic, V.: Application of airborne LiDAR to mapping seismogenic faults in forested mountainous terrain, southeastern Alps, Slovenia, Geophys. Res. Lett., 33, L20308, https://doi.org/10.1029/2006GL027014, 2006.

Cunningham, D., Gosar, A. Kastelic, V. Grebby, S., and Tansey, K.: Multi-disciplinary investigations of active faults in the Julian Alps, Slovenia, Acta Geodyn. Geomater., 4, 77-85, 2007.

D’Agostino, N., Avallone, A., Cheloni, D., D'Anastasio, E., Mantenuto, S., and Selvaggi, G.: Active tectonics of the Adriatic region from GPS and earthquake slip vectors, J. Geophys. Res., 113, B12413, https://doi.org/10.1029/2008JB005860, 2008.

Devoti, R., Esposito, A., Pietrantonio, G., Pisani, A. R., and Riguzzi, F.: Evidence of large scale deformation patterns from GPS data in the Italian subduction boundary, Earth Planet. Sc. Lett., 311, 230-241, 2011.

Doglioni, C. and Bosellini, A.: Eoalpine and mesoalpine tectonics in the Southern Alps, Geol. Rundsch., 76, 735-754, 1987.

Fitzko, F., Suhadolc, P., Aoudia, A., and Panza, G. F.: Constrains on the location and mechanism of the 1511 Western-Slovenia earthquake from active tectonics and modeling of macroseismic data, Tectonophysis, 404, 77-90, 2005.

Galadini, F., Poli, M. E., and Zanferrari, A.: Seismogenic sources potentially responsible for earthquakes with $M \geq 6$ in the eastern Southern Alps (Thiene-Udine sector, NE Italy), Geophys. J. Int., 161, 739-762, https://doi.org/10.1111/j.1365246X.2005.02571.x, 2005
Kastelic, V., Vrabec, M., Cunningam, D., and Gosar, A.: NeoAlpine structural evolution and present day tectonic activity of the eastern Southern Alps: the case of the Ravne fault, NW Slovenia, J. Struct. Geol., 30, 963-965, 2008.

King, G., Klinger, Y., Bowman, D., and Tapponier, P.: Slippartitioned surface break for the $M_{\mathrm{W}} 7.82001$ Kokoxili earthquake, China, B. Seismol. Soc. Am., 95, 731-738, 2005.

Košir, M. and Cecić I.: Potres 26. marca 1511 v luči novih raziskav. Idrijski razgledi, 56/1, 90-104, 2011.

Locati, M., Camassi, R., Rovida, A., Ercolani, E., Bernardini, F., Castelli, V., Caracciolo, C. H., Tertulliani, A., Rossi, A., Azzaro, R., D'Amico, S., Conte, S., and Rocchetti, E.: DBMI15, the 2015 version of the Italian Macroseismic Database. Istituto Nazionale di Geofisica e Vulcanologia, https://doi.org/10.6092/INGV.ITDBMI15, 2016.

Marton, E., Drobne K., Cosovic V., and Moro, A.: Palaeomagnetic evidence of Tertiary counterclockwise rotation of Adria, Tectonophysiscs, 377, 143-156, 2003.

Mlakar, I.: Krovna zgradba idrijsko Zirovskega ozamlja, Geologija, 12, 5-72, 1969.

Monegato, G. and Poli, M. E.: Tectonic and climatic inferences from the terrace staircase in the Meduna valley, eastern Southern Alps, NE Italy, Quatern. Res., 83, 229-242, 2015.

Montone, P. and Mariucci, M. T.: The new release of the Italian contemporary stress map, Geophys. J. Int. 205, 1525-1531, 2016.

Moulin, A., Benedetti, L., Gosar, A., Rupnik, P. J., Rizza, M., Bourlès, D., and Ritz, J. F.: Determining the present-day kinemtics of the Idrija fault (Slovenia) from airborne LiDAR topography, Tectonophysics, 628, 188-205, 2014.

Moulin, A., Benedetti, L., Rizza, M., Rupnik, P. J., Gosar, A., and Bourlès, D.: The Dinaric fault system: Large-scale structure, rates of slip, and Plio-Pleistocene evolution of the transpressive northeastern boundary of the Adria microplate, Tectonics, 35, 2258-2292, 2016.

Placer, L., Vrabec M., and Ceralac, B.: The bases for understanding of the NW Dinarides and Istria Peninsula tectonics, Geologija, 53/1, 55-86, Ljubljana, Slovenia, https://doi.org/10.5474/geologija.2010.005, 2010.

Poli, M. E. and Renner, G.: Normal focal mechanisms in the Julian Alps and Prealps: seismotectonic implications for the ItalianSlovenian border region, B. Geofis. Teor. Appl., 45, 51-69, 2004.

Poli, M. E., Peruzza, L., Rebez, A., Renner, G., Slejko, D., and Zanferrari, A.: New seismotectonic evidence from analysis of the 1976-1977 and 1977-1999 seismicity in Friuli (NE Italy), B. Geofis. Teor. Appl., 43, 1-2, 53-78, 2002.

Poli, M. E., Burrato, P., Galadini, F., and Zanferrari, A.: Seismogenic sources responsible for destructive earthquakes in NE Italy, B. Geofis. Teor. Appl., 49, 301-313, 2008.

Poli, M. E., Zanferrari A., and Monegato, G.: Geometria, cinematica e attività pliocenico-quaternaria del sistema di sovrascorrimenti Arba-Ragogna (Alpi Meridionali orientali, Italia NE), Rendiconti online Soc. Geol. It., 5, 172-175, 2009.

Poljak, M., Gosar, A., and Živcič, M.: Active tectonics in Slovenia, in: Geology of Adriatic Area, Geo Acta Special Pubblication, 3, 15-24, 2010.

Pondrelli, S., Ekstro, G., and Morelli, A.: Seismotectonic reevaluation of the 1976 Friuli, Italy, seismic sequence, J. Seismol., 5, 73-83, 2001. 
Reimer, P. J., Bard, E., Bayliss, A., Beck, J. W., Blackwell, P. G., Bronk Ramsey, C., Buck, C. E., Cheng, H., Edwards, R. L., Friedrich, M., Grootes, P. M., Guilderson, T. P., Haflidason, H., Hajdas, I., Hatté, C., Heaton, T. J., Hoffmann, D. L., Hogg, A. G., Hughen, K. A., Kaiser, K. F., Kromer, B., Manning, S. W., Niu, M., Reimer, R. W., Richards, D. A., Scott, E. M., Southon, J. R., Staff, R. A., Turney, C. S. M., and Van der Plicht, J.: IntCal13 and Marine13 radiocarbon age calibrations curves 0-50 000 years cal BP. Radiocarbon, 55, 1869-1887, 2013.

Ribaric, V.: The Idrija earthquake of March 26, 1511 a reconstruction of some seismological parameters, Tectonophysics, 53, 315324, 1979.

Rovida, A., Locati, M., Camassi, R., Lolli B., and Gasperini, P. (Eds.): CPTI15, the 2015 version of the Parametric Catalogue of Italian Earthquakes, Istituto Nazionale di Geofisica e Vulcanologia, https://doi.org/10.6092/INGV.IT-CPTI15, 2016.

Serpelloni, E., Vannucci, G., Anderlini, L., and Bennett, R. A.: Kinematics, seismotectonics and seismic potential of the eastern sector of the European Alps from GPS and seismic deformation data, Tectonophysics, 688, 157-181, https://doi.org/10.1016/j.tecto.2016.09.026, 2016.

Slejko, D., Camassi, R., Cecić, I., Herak, D., Herak, M., Kociu, S., Kouskouna, V., Lapajne, J., Makropoulos, K., Meletti, C., Muço, B., Papaioannou, C., Peruzza, L., Rebez, A., Scandone, P., Sulstarova, E., Voulgaris, N., Zîvčić, M., and Zupancîč, P.: Seismic hazard assessment for Adria, Ann. Geophys.-Italy, 42, 1085-1107, 1999.

Vrabec, M.: Some thoughts on the pull-apart origin of karst poljes along the Idrija strike slip fault in Slovenia, Acta Carseologica, XXIII, 155-167, Liubljana, Slovenia, 1994.

Vrabec, M. and Fodor, L.: Late Cenozoic tectonics of Slovenia: Structural styles at the northeastern corner of the Adriatic microplate, in: The Adria microplate: GPS geodesy, tectonics, and hazards, edited by: Pinter, N., Grenerczy, G., Weber, J., Stein, S., and Medak, D., Springer, the Netherlands, 151-168, 2006.

Walker, R., Jackson, J., and Baker, C.: Surface expression of thrust faulting in eastern Iran: source parameters and surface deformation of the 1978 Tabas and 1968 Ferdows earthquake sequences, Geophys. J. Int., 152, 749-765, 2003.
Wells, D. L. and Coppersmith, K. J.: Analysis of empirical relationships among magnitude, rupture length, rupture area, and surface displacement, B. Seismol. Soc. Am., 84, 974-1002, 1994.

Wesnousky, S. G. and Jones, C. H.: Oblique slip, slip partitioning, spatial and temporal changes in the regional stress field, and relative strength of active faults in the Basin and Range, western United States, Geology, 22, 1031-1034, 1994.

Zanferrari, A., Bollettinari, G., Carobene, L., Carton, A., Carulli, G. B., Castaldini, D., Cavallin, A., Panizza, M., Pellegrini, G. B., Pianetti, F., and Sauro, U.: Evoluzione neotettonica dell'Italia nord-orientale, Mem. Sci. Geol., 35, 355-376, 1982.

Zanferrari, A., Avigliano, R., Monegato, G., Paiero, G., Poli, M. E., and Stefani, C.: Geological map and explanatory notes of the Geological Map of Italy at the scale 1:50.000: Sheet 066 "Udine". APAT-Servizio Geologico d'Italia - Regione Autonoma Friuli Venezia Giulia, 176 pp., available at: http://www.isprambiente. gov.it/Media/carg/friuli.html (last access: 16 July 2018), 2008a.

Zanferrari, A., Avigliano, R., Grandesso, P., Monegato, G., Paiero, G., Poli, M. E., and Stefani, C.: Geological map and explanatory notes of the Italian Geological Map at the scale 1:50.000: Sheet 065 "Maniago". APAT-Servizio Geologico d'Italia - Regione Autonoma Friuli Venezia Giulia, available at: http://www. isprambiente.gov.it/Media/carg/friuli.html (last access: 16 July 2018), 2008b.

Zanferrari, A., Masetti, D., Monegato, G., and Poli, M. E.: Geological map and explanatory notes of the Geological Map of Italy at the scale 1:50.000: Sheet 049 "Gemona del Friuli". ISPRA - Servizio Geologico d'Italia - Regione Autonoma Friuli Venezia Giulia, 262 pp., available at: http://www.isprambiente. gov.it/Media/carg/friuli.html (last access: 16 July 2018), 2013.

Zupancîč, P., Cecić I., Gosar A., Placer, L., Poljak, M., and Zîvčić, M.: The earthquake of 12 April 1998 in the Krn Mountains (Upper Soča valley, Slovenia) and its seismotectonic characteristics, Geologija, 44, 169-192, 2001. 